\title{
POSTĘPOWANIE W SPRAWIE WYDANIA POZWOLENIA NA BUDOWE, W KTÓRYM WYMAGANY JEST UDZIAŁ SPOKECZEŃSTWA, ZE SZCZEGÓLNYM UWZGLĘDNIENIEM ZGŁOSZENIA UDZIAŁU W NIM ORGANIZACJI EKOLOGICZNYCH
}

\section{Wstęp}

Przedmiotem niniejszego artykułu są rozważania nad postępowaniem w sprawie wydania pozwolenia na budowę, w którym uczestnictwo z racji wymaganego w nim udziału społeczeństwa zgłaszają organizacje ekologiczne. W celu pełnego zobrazowania wskazanej problematyki niezbędnym jest określenie, w jego treści, w jakich przypadkach polski ustawodawca przewidział wymóg udziału społeczeństwa w postępowaniu w sprawie wydania pozwolenia na budowę, jaki wpływ na to postepowanie ma raport oddziaływania przedsięwzięcia na środowisko, a także czym jest organizacja ekologiczna.

\section{Postępowanie wymagające udziału społeczeństwa}

„Postępowaniem wymagającym udziału społeczeństwa jest tylko takie postępowanie, co do którego wymóg zapewnienia udziału społeczeństwa jest przewidziany konkretnym przepisem administracyjnego prawa materialnego". ${ }^{1}$ Jest to subprocedura, której celem jest zapewnienie udziału społeczeństwa w postępowaniu głównym. ${ }^{2}$

\footnotetext{
1 Zob. Wyrok WSA w Szczecinie z dnia 27 marca 2013 r., sygn. akt: I SA/Sz 53/13; wyrok NSA z 1 lutego 2012 r., sygn. akt: II OSK 2580/11; wyrok NSA z 10 października 2012 r., sygn. akt: II OSK 1085/11.

2 Zob. M. Micińska, Udział społeczeństwa w ochronie środowiska. Instrumenty administracyjno-prawne, Toruń 2011, s. 147.
} 
$\mathrm{Z}$ treści przepisu art. 3 ust. 1 pkt 8 ustawy z dnia 3 października 2008 r. o udostępnianiu informacji o środowisku i jego ochronie, udziale społeczeństwa w ochronie środowiska oraz o ocenach oddziaływania na środowisko ${ }^{3}$ wynika, iż udział społeczeństwa zagwarantowany jest w postępowaniu, w którym dokonywana jest ocena oddziaływania na środowisko planowanego przedsięwzięcia, a więc w tzw. postępowaniu głównym. Uregulowanie tej kwestii w słowniczku ustawowym znajduje swe odzwierciedlenie w dalszej części wskazanej regulacji prawnej. Ustawodawca bowiem w jej przepisie art. 79 ust. 1 nakłada na organ właściwy do wydania decyzji o środowiskowych uwarunkowaniach, przed podjęciem rozstrzygnięcia, obowiązek zapewnienia możliwości udziału społeczeństwa w postępowaniu, w ramach którego przeprowadza ocenę oddziaływania na środowisko. Stosownie do przepisu art. 61 ust. 1 pkt 2 ustawy o udostępnianiu informacji o środowisku, taką ocenę przeprowadza się m.in. w postępowaniu dotyczącym wydawanej w oparciu o ustawę z dnia 7 lipca 1994 r. - Prawo budowlane ${ }^{4}$ decyzji o pozwoleniu na budowę. Przeprowadzenie oceny oddziaływania na środowisko planowanego przedsięwzięcia w takiego rodzaju postępowaniu następuje wówczas, gdy konieczność jej przeprowadzenia została stwierdzona przez organ właściwy do wydania decyzji o środowiskowych uwarunkowaniach oraz gdy podmiot planujący podjęcie realizacji przedsięwzięcia złoży wniosek o jej przeprowadzenie do organu właściwego do wydania decyzji, a także w sytuacji, w której organ właściwy do wydania decyzji stwierdzi, że we wniosku o wydanie decyzji zostały dokonane zmiany w stosunku do wymagań określonych w decyzji o środowiskowych uwarunkowaniach.

W postępowaniu w sprawie wydania decyzji o pozwoleniu na budowę udział społeczeństwa jest wymagany wyłącznie w przypadku ponownego przeprowadzania oceny oddziaływania przedsięwzięcia na środowisko (art. 88 ust. 1 i art. 90 ust. 2 pkt 1 ustawy o udostępnianiu informacji o środowisku). Ponowna ocena oddziaływania przedsięwzięcia na środowisko w postępowaniu dotyczącym wydania pozwolenia na budowę jest przeprowadzana w trzech następujących przypadkach: 1) gdy konieczność jej przeprowadzenia została stwierdzona przez organ właściwy do wydania decyzji o środowiskowych uwarunkowaniach (art. 61 ust. 1 pkt 2 w związku z art. 72 ust. 1 pkt 1 ustawy o udostępnianiu informacji o środowisku); 2) gdy podmiot planujący podjęcie realizacji przedsięwzięcia złoży wniosek o jej przeprowadzenie do organu właściwego do wydania decyzji (art. 88 ust. 1 pkt 1 ustawy o udostępnianiu informacji o środowisku); 3) gdy organ właściwy do wydania decyzji stwierdzi, że we wniosku o wydanie decyzji o pozwoleniu na budowę zostały dokonane zmiany w stosunku do wymagań określonych w decyzji o środowiskowych uwarunkowaniach (art. 88 ust. 1 pkt 2 ustawy o udostępnianiu informacji o środowisku). ${ }^{5}$

Dz.U. z 2008 r. Nr 199, poz. 1227 z późn. zm.

Dz.U. z 2010 r. Nr 243, poz. 1623 z późn. zm.

Zob. wyrok NSA z 1 lutego 2012 r., sygn. akt: II OSK 2580/11. 


\section{Raport oddziaływania przedsięwzięcia na środowisko a postępowanie w sprawie wydania pozwolenia na budowę, w którym wymagany jest udział społeczeństwa}

Organ administracji architektoniczno-budowlanej prowadzący postępowanie w sprawie wydania pozwolenia na budowę, w którym wymagany jest udział społeczeństwa, ${ }^{6} \mathrm{w}$ sytuacji, gdy ocena oddziaływania przedsięwzięcia na środowisko przeprowadzana jest na wniosek podmiotu planującego podjęcie realizacji przedsięwzięcia, jak i w przypadku przeprowadzenia jej z urzędu, zobowiązany jest zawiesić postępowanie główne do czasu przedłożenia mu przez wnioskodawcę raportu o oddziaływaniu przedsięwzięcia na środowisko. ${ }^{7}$ Samodzielną podstawą prawną do wydania postanowienia o zawieszeniu jest przepis art. 88 ust. 4 ustawy o udostępnianiu informacji o środowisku. ${ }^{8}$ Przedłożenie przez wnioskodawcę raportu o oddziaływaniu przedsięwzięcia na środowisko warunkuje więc dalsze prowadzenie postępowania $\mathrm{w}$ przedmiocie wydania pozwolenia na budowę. Podjęcie postępowania następuje w trybie przepisu art. $97 \S 2$ k.p.a. w związku z art. 88 ust. 4 ustawy o udostępnianiu informacji o środowisku. $\mathrm{Z}$ literalnego brzmienia przepisu art. 88 ust. 4 ustawy o udostępnianiu informacji o środowisku wynika, iż podjęcie postępowania powinno nastąpić niezwłocznie po przedłożeniu ww. raportu, co nie jest tożsame z zakończeniem postępowania w przedmiocie dokonania oceny oddziaływania przedsięwzięcia na środowisko. ${ }^{9}$ Przykładowo W. Radecki wskazuje jednak, iż organ administracji architektoniczno-budowlanej, prowadzący postępowanie w przedmiocie wydania pozwolenia na budowę, ,zawiesza postępowanie do czasu zakończenia oceny oddziaływania przedsięwzięcia na środowisko" i dopiero po wydaniu przez

6 Organem administracji architektoniczno-budowlanej pierwszej instancji właściwym w sprawach o wydanie pozwolenia na budowę jest co do zasady starosta, a w przypadkach określonych w przepisie art. 82 ust. 3 Prawa budowlanego wojewoda. W myśl tej regulacji prawnej wojewoda, jako organ pierwszej instancji, wydaje pozwolenia na budowę w sprawach obiektów i robót budowlanych: 1) usytuowanych na terenie pasa technicznego, portów i przystani morskich, morskich wód wewnętrznych, morza terytorialnego i wyłącznej strefy ekonomicznej, a także na innych terenach przeznaczonych do utrzymania ruchu i transportu morskiego; 2) hydrotechnicznych piętrzących, upustowych, regulacyjnych, melioracji podstawowych oraz kanałów i innych obiektów służących kształtowaniu zasobów wodnych i korzystaniu z nich, wraz z obiektami towarzyszącymi; 3) dróg publicznych krajowych i wojewódzkich wraz z obiektami i urządzeniami służącymi do utrzymania tych dróg i transportu drogowego oraz sytuowanymi w granicach pasa drogowego sieciami uzbrojenia terenu - niezwiązanymi $z$ użytkowaniem drogi, a w odniesieniu do dróg ekspresowych i autostrad - wraz z obiektami i urządzeniami obsługi podróżnych, pojazdów i przesyłek; 3a) usytuowanych na obszarze kolejowym; 4) lotnisk cywilnych wraz z obiektami i urządzeniami towarzyszącymi; 5) usytuowanych na terenach zamkniętych. Ponadto w przepisie art. 82 ust. 4 Prawa budowlanego zawarte zostało upoważnienie ustawowe dla Rady Ministrów do wskazania w drodze rozporządzenia, innych niż w ww. katalogu, obiektów i robót budowlanych, w których do orzekania w pierwszej instancji właściwy będzie wojewoda.

7 Zob. K. Gruszecki, Ustawa o udostępnianiu informacji o środowisku i jego ochronie, udziale społeczeństwa w ochronie środowiska oraz o ocenach oddziaływania na środowisko. Komentarz, Wrocław 2009, s. 274; Zob. B. Rakoczy, Ustawa o udostępnianiu informacji o środowisku i jego ochronie, udziale społeczeństwa w ochronie środowiska oraz o ocenach oddziaływania na środowisko. Komentarz, Warszawa 2010, s. 245.

8 Zob. B. Rakoczy, Ustawa o udostępnianiu informacji, op. cit., s. 245.

9 Por. K. Gruszecki, Udostępnianie informacji o środowisku i jego ochronie, udział społeczeństwa w ochronie środowiska oraz oceny oddziaływania na środowisko. Komentarz, Lex 2013, Nr 8775. 
właściwy organ postanowienia uzgadniającego, podejmuje je, a następnie rozstrzyga sprawę w pierwszej instancji. ${ }^{10}$ Podobnie uważa K. Gruszecki. ${ }^{11}$

Wydanie postanowienia o podjęciu zawieszonego postępowania jest niezbędne, aby organ administracji architektoniczno-budowlanej mógł przystąpić do kolejnego jego etapu. Po otrzymaniu raportu na podstawie przepisu art. 89 ust. 1 ustawy o udostępnianiu informacji o środowisku obowiązany jest on bowiem wystąpić do Regionalnego Dyrektora Ochrony Środowiska albo Generalnego Dyrektora Ochrony Środowiska z wnioskiem o uzgodnienie warunków realizacji przedsięwzięcia przedkładając mu jednocześnie: 1) wniosek o wydanie pozwolenia na budowę; 2) decyzję o środowiskowych uwarunkowaniach; oraz 3) raport o oddziaływaniu przedsięwzięcia na środowisko. Następnie organ, który przeprowadził ocenę, wydaje postanowienie w sprawie uzgodnienia warunków realizacji przedsięwzięcia. To właśnie przed jego wydaniem, w oparciu o przepis art. 90 ust. 2 pkt 1 ustawy o udostępnianiu informacji o środowisku, występuje on do organu prowadzącego postępowanie główne o zapewnienie możliwości udziału w nim społeczeństwa. Dopiero, gdy organ administracji architektoniczno-budowlanej, na zasadach określonych $\mathrm{w}$ przepisach art. 33-36 i 38 ww. ustawy zapewni społeczeństwu udział w postępowaniu, organizacja ekologiczna może uzyskać status podmiotu działającego w tym postępowaniu na prawach strony.

\section{Organizacja ekologiczna a organizacja społeczna}

Organizacją ekologiczną w rozumieniu przepisu art. 3 pkt 10 ustawy o udostępnianiu informacji o środowisku są organizacje społeczne, których statutowym celem jest ochrona środowiska. Nie definiuje ona jednak pojęcia „organizacji społecznej”, a w przedmiocie definicji ,środowiska" odsyła do ustawy z dnia 27 kwietnia $2001 \mathrm{r}$. - Prawo ochrony środowiska. ${ }^{12}$ Jak słusznie zauważył B. Draniewicz: ,ustawodawca posłużył się tutaj klasyczną definicją per genus proximum et differentiam specificam (przez rodzaj najbliższy i różnicę gatunkową). Tym rodzajem jest organizacja społeczna, a różnicą gatunkową ochrona środowiska jako cel statutowy". ${ }^{13}$

W polskim ustawodawstwie brak jest definicji legalnej organizacji społecznej wyjaśniającej jej istotę. Zgodnie z przepisem art. $5 \S 2$ pkt 5 k.p.a. ${ }^{14}$ za organizacje społeczne uważa się organizacje zawodowe, samorządowe, spółdzielcze i inne organizacje społeczne. Takie przykładowe wyliczenie podmiotów mających status organizacji społecznych nie ujmuje istoty problemu, zwłaszcza że ustawodawca

\footnotetext{
10 Por. W. Radecki, Instytucje prawa ochrony środowiska. Geneza, rozwój, perspektywy, Warszawa 2010, s. 297298; zob. także W. Radecki, Ochrona walorów turystycznych w prawie polskim, Lex 2011, Nr 134173.

K. Gruszecki, Ustawa o udostępnianiu informacji..., op. cit., s. 274.

Dz.U. z 2008 r. Nr 25, poz. 150 t.j.

B. Draniewicz, Glosa do wyroku WSA w Warszawie z 11 sierpnia 2010 r. (IV SA/Wa 857/10), „Prawo i Środowisko" 2010, nr 4, s. 97 i 98.

14 Ustawa z dnia 14 czerwca 2013 r. - Kodeks postępowania administracyjnego Dz.U. z 2013 r., poz. 267 t.j.
} 
wskazał, iż przez organizacje społeczne należy rozumieć także ,inne organizacje społeczne", nadając tej definicji walor katalogu otwartego. Z uwagi na powyższe kwestia ta jest przedmiotem rozważań doktryny oraz orzecznictwa sądowo-administracyjnego. Punktem odniesienia przy definiowaniu tego zagadnienia jest wskazanie cech charakterystycznych, które musi posiadać dany podmiot, aby zostać uznanym za organizację społeczną. Przykładowo G. Łaszcyca jako niezbędne cechy organizacji społecznej wymienia: 1) substrat osobowy, czyli zrzeszanie się osób fizycznych lub prawnych; 2) legalność, a więc działanie na podstawie przepisów prawa powszechnie obowiązującego i w formie przez to prawem przewidzianej; 3) trwałość celu; 4) cel o charakterze społecznym, gospodarczym, politycznym i kulturalnym; 5) funkcjonowanie poza strukturą aparatu państwa. ${ }^{15}$ Według J. Sommera organizacją społeczną jest zrzeszenie posiadające określone cechy strukturalne, takie jak: 1) oparcie na dobrowolnym członkostwie; 2) posiadanie autonomii organizacyjnej; 3) trwały charakter; 4) dążenie do realizacji celów szerszych niż tylko zaspokajanie bezpośrednich potrzeb swoich członków. ${ }^{16} \mathrm{M}$. Bogusz wskazuje, iż organizacja społeczna to: ,a) trwałe zrzeszenie osób fizycznych lub prawnych, b) działające $\mathrm{w}$ formie prawnej przewidzianej przez przepisy powszechnie obowiązujące (organizacja «nazwana» przez obowiązujące prawo), c) nie wchodzące w skład aparatu państwa, d) posiadające cel o charakterze społecznym". ${ }^{17}$ B. Jaworska-Dembska jako niezbędne cechy, którymi powinien się wyróżniać podmiot będący organizacją społeczną wymienia: , (...) 1) trwały cel o charakterze społecznym, 2) obowiązek opierania swej działalności na podstawie prawnej, 3) uznanie przez państwo, 4) normy organizacyjne wiążą tylko członków, 5) obowiązek realizacji celów statutowych spoczywa wyłącznie na członkach. (...)" ${ }^{18}$ Według A. Gronkiewicz do niezbędnych cech organizacji społecznych, przy uwzględnieniu najnowszego orzecznictwa sądowo-administracyjnego, należy zaliczyć: „1) funkcjonowanie poza sektorem państwowym i gospodarczym; 2) cel o charakterze społecznym; 3) trwałość celu; 4) charakter dobrowolny organizacji w sensie dobrowolności przynależności członków organizacji; 5) autonomia organizacyjna”. ${ }^{19}$ P. Przybysz za organizację społeczną uważa: „dobrowolne zrzeszenie osób fizycznych lub osób prawnych, niewchodzące w skład aparatu państwowego, zmierzające do realizacji postawionych przed sobą celów o charakterze niegospodarczym, tj. celów kulturalnych, społecznych, edukacyjnych itp." ${ }^{20}$ Kluczowym orzeczeniem Naczelnego Sądu Administracyjnego w tym zakresie jest uchwała 7 sędziów z dnia 12 grudnia 2005 r., której zawdzięcza się ugrunto-

\footnotetext{
15 Zob. W. Federczyk, M.Klimaszewski, B. Majchrzak, Postępowanie administracyjne, Warszawa 2013, s. 72.

16 Zob. A. Gronkiewicz, Organizacja społeczna w ogólnym postępowaniu administracyjnym, Warszawa 2012, s. 57 i 58 .

17 M. Bogusz, Zaskarżenie decyzji administracyjnej do Naczelnego Sądu Administracyjnego, Warszawa 1997, s. 43.

18 B. Jaworska-Dembowska, Pozycja organizacji społecznych w kodeksie postępowania administracyjnego, „Państwo i Prawo" 1980, z. 11, s. 57.

19 Zob. A. Gronkiewicz, Organizacja społeczna w ogólnym..., op. cit., s. 62.

20 P. Przybysz, Kodeks postępowania administracyjnego. Komentarz, Warszawa 2012, s. 35.
} 
wanie poglądu, według którego fundacja, po spełnieniu określonych cech, uzyskuje status organizacji społecznej. ${ }^{21} \mathrm{~W}$ treści jego uzasadnienia wskazano, że wszystkie organizacje społeczne posiadają 5 następujących cech: ,a) są to organizacje obejmujące wyodrębniony zespół osób, oparte na dobrowolności przynależności do nich; b) do organizacji tych odnosi się właściwy zespół przepisów określających ich strukturę, zakres praw i obowiązków stanowiący o ich organizacyjnej odrębności i samodzielności; c) działalność i cele organizacji określone są przede wszystkim statutem i muszą pozostawać w zgodzie z celami państwa; d) organy tych organizacji pochodzą z wyboru tych, którzy te organizacje tworzą; e) organizacje, o których powyżej mowa pozostają pod kontrolą lub nadzorem organów władzy publicznej”. ${ }^{22}$ Zdaniem A. Gronkiewicz wyrażone w przedmiotowej uchwale Naczelnego Sądu Administracyjnego stanowisko „nie jest wprawdzie tożsame z definicją organizacji społecznej oraz nie może jej zastępować, ale rekomenduje określony kierunek, w którym powinny podążać organy ustawodawcze przy tworzeniu prawa, jak i organy wykonawcze przy jego stosowaniu". ${ }^{23}$

W świetle powyższych rozważań można wskazać, iż organizacja ekologiczna to podmiot, który: 1) jest wyodrębniony organizacyjnie; 2) działa na podstawie i w granicach prawa; 3) ma trwały charakter; 4) zrzesza na zasadach dobrowolności osoby fizyczne lub prawne; 5) nie wchodzi w skład aparatu państwa, ale podlega jego kontroli; 6) działa w interesie społecznym; 7) jego celem statutowym jest ochrona środowiska. Może nią być również fundacja. Dla porównania K. Gruszecki definiuje organizację ekologiczną jako podmiot, który jest wyodrębniony organizacyjnie, działa legalnie i prowadzi działalność w zakresie ochrony środowiska. ${ }^{24}$

„Określenie «cel statutowy» oznacza, że sprawa dotyczy zasadniczych kierunków działalności danej organizacji, zapisanych w statucie lub w innym, spełniającym podobną do statutu funkcję, akcie regulującym wewnętrzny ustrój danej organizacji społecznej". ${ }^{25}$ Celem statutowym organizacji ekologicznej jest ochrona środowiska. Zgodnie z przepisem art. 3 pkt 39 ustawy Prawo ochrony środowiska przez „środowisko" należy rozumieć ogół elementów przyrodniczych, w tym także przekształconych w wyniku działalności człowieka, a w szczególności powierzchnię ziemi, kopaliny, wody, powietrze, krajobraz, klimat oraz pozostałe elementy różnorodności biologicznej, a także wzajemne oddziaływania pomiędzy tymi elementami. Jego ochrona natomiast to, zgodnie z przepisem art. 3 pkt 13 Prawa ochrony środowiska, podjęcie lub zaniechanie działań, umożliwiające zachowanie lub przywra-

Uchwała NSA z dnia 12 grudnia 2005 r., sygn. akt: Il OSP 4/05.

Ibidem.

Zob. A. Gronkiewicz, Organizacja społeczna w ogólnym..., op. cit., s. 61.

K. Gruszecki, Organizacje ekologiczne, (w:) Zezwolenia na usunięcie drzew i krzewów, Lex 2010, Nr 121758; zob. K. Gruszecki, Udział organizacji ekologicznych w postępowaniu administracyjnym w sprawach ochrony środowiska, „Państwo i Prawo” 2002, z. 2, s. 91.

Wyrok WSA w Warszawie z dnia 19 kwietnia 2013 r., sygn. akt: IV SA/Wa 185/13; zob. Wyrok WSA w Warszawie z dnia 22 września 2005 r., sygn. akt: IV SA/Wa 736/04. 
Postępowanie w sprawie wydania pozwolenia na budowę...

canie równowagi przyrodniczej. Polega ona w szczególności na: 1) racjonalnym kształtowaniu środowiska i gospodarowaniu zasobami środowiska zgodnie z zasadą zrównoważonego rozwoju; 2) przeciwdziałaniu zanieczyszczeniom; 3) przywracaniu elementów przyrodniczych do stanu właściwego. Ochrona środowiska nie musi być ani jedynym, ani głównym celem statutowym danego podmiotu, aby można go było uznać za organizację ekologiczną. Ustawodawca nie wprowadził w tym zakresie ograniczenia, w związku z czym należy stosować tu wykładnię rozszerzającą. ${ }^{26}$

\section{Zgłoszenie udziału organizacji ekologicznej w postępowaniu w sprawie pozwolenia na budowę, w którym wymagany jest udział społeczeństwa}

\section{Podstawa prawna}

Zasadą jest, iż w postępowaniach dotyczących wydania pozwolenia na budowę udział organizacji społecznych, działających w nim na prawach strony, jest wykluczony. Zgodnie bowiem z art. 28 ust. 3 Prawa budowlanego przepisów art. 31 k.p.a. nie stosuje się w postępowaniu w sprawie wydania pozwolenia na budowę. Wyjątek od tej zasady przewiduje przepis art. 28 ust. 4 Prawa budowlanego i dotyczy postępowań w sprawie pozwolenia na budowę wymagających udziału społeczeństwa zgodnie z przepisami ustawy o udostępnianiu informacji o środowisku. W takich bowiem postępowaniach na mocy przepisu art. 44 ust. 1 ww. ustawy mogą uczestniczyć organizacje ekologiczne na prawach strony, do których jak wynika z przepisu art. 28 ust. 3 i 4 Prawa budowlanego mają odpowiednie zastosowanie przepisy art. $31 \S 1-3$ i 5 k.p.a. W rzeczywistości jednak do organizacji ekologicznych zgłaszających swój udział w postępowaniu wymagającym udziału społeczeństwa odpowiednie stosowanie dotyczy przepisu art. $31 \S 5$ k.p.a. ${ }^{27}$ Fakt, iż organizacja ekologiczna działa na prawach strony w powyższym postępowaniu wynika wprost $\mathrm{z}$ treści art. 44 ustawy o udzielaniu informacji o środowisku, stanowiącym lex specialis w stosunku do Kodeksu postępowania administracyjnego, wskazuje tym samym na bezcelowość odwoływania się w tej materii do przepisu art. $31 \S 3$ k.p.a.

\section{Uczestnictwo na prawach strony}

Na podstawie przepisu art. 44 ust. 1 ustawy o udostępnianiu informacji o środowisku organizacje ekologiczne, które powołując się na swoje cele statutowe zgłoszą chęć uczestnictwa w określonym postępowaniu wymagającym udziału społeczeństwa uczestniczą w nich na prawach strony. Nie stosuje się w tym przypadku przepisu art. $31 \S 4$ Kodeksu postępowania administracyjnego. W związku z czym organ

\footnotetext{
26 Zob. Wyrok NSA z dnia 13 grudnia 2011 r., sygn. akt: II OSK 1732/10; por. A. Gronkiewicz, Organizacja społeczna w ogólnym..., op. cit., s. 217.

27 Por. K. Gruszecki, Ustawa o udostępnianiu informacji..., op. cit., s. 122-123.
} 
administracji publicznej prowadzący postępowanie wymagające udziału społeczeństwa nie ma obowiązku zawiadomić organizacji ekologicznej o wszczęciu postępowania $\mathrm{z}$ uwagi na jej cele statutowe oraz interes społeczny. Organizacja ekologiczna przystępuje więc do postępowania $\mathrm{z}$ własnej inicjatywy, a warunkiem koniecznym jaki musi spełnić, aby móc w nim uczestniczyć na prawach strony jest powołanie się na swoje cele statutowe, a więc na ochronę środowiska. Dopuszczenie organizacji ekologicznej do udziału na prawach strony w postępowaniu wymagającym udziału społeczeństwa następuje ex lege na skutek złożonego przez nią wniosku. Organ może jednak zgodnie z przepisem art. 44 ust. 4 ustawy o udostępnieniu informacji o środowisku postanowieniem, na które przysługuje zażalenie, odmówić udziału w postępowaniu wnioskującej organizacji. Następuje to wówczas, gdy zgłaszający swój udział podmiot nie jest organizacją ekologiczną w rozumieniu przedmiotowej ustawy bądź postępowanie, w którym zgłasza swój udział nie wymaga udziału społeczeństwa. Są to dwie kluczowe przesłanki, które organ administracji architektoniczno-budowlanej obowiązany jest zbadać w przypadku, gdy dany podmiot zgłasza swoje uczestnictwo w postępowaniu w oparciu o przepis art. 44 ust. 1 ustawy o udostępnianiu informacji o środowisku. Gdy któraś z nich nie zostanie spełniona, to mając na uwadze przepis art. 28 ust. 3 Prawa budowlanego, udział organizacji społecznej w postępowaniu w przedmiocie wydania pozwolenia na budowę będzie wykluczony. Nie znajdzie tu zastosowania pogląd, zgodnie z którym „organizacje ekologiczne w postępowaniach, w których udział społeczeństwa nie jest wymagany, będą mogły uczestniczyć na ogólnych zasadach, a zatem po spełnieniu wymagań wynikających z art. $31 \S 1$ k.p.a., czyli gdy cel statutowy organizacji jest zgodny z przedmiotem postępowania oraz za udziałem organizacji w postępowaniu przemawia interes społeczny". ${ }^{28}$

Interesującym przykładem braku legitymacji do dokonania zgłoszenia uczestnictwa w postępowaniu wymagającym udziału społeczeństwa, a w związku z tym również braku możliwości uzyskania statusu podmiotu na prawach strony, jest złożenie w tym przedmiocie wniosku przez organizację ekologiczną będącą w likwidacji. Rozwiązanie organizacji przez sąd oznacza zakończenie wszelkiej jej działalności. Powołany likwidator działa tylko w celu zakończenia spraw majątkowych, nie kontynuuje zatem działalności statutowej organizacji. ${ }^{29} \mathrm{~W}$ konsekwencji z chwilą rozwiązania przez sąd traci ona możliwość wykonywania swoich celów statutowych i tym samym nie może skutecznie zgłosić uczestnictwa w postępowaniu wymagającym udziału społeczeństwa ani brać w nim czynnego udziału. Tak więc w przypadku, gdy podmiot zgłaszający swój udział w postępowaniu wymagającym udziału społeczeństwa nie ma statusu organizacji ekologicznej, organ administracji architektoniczno-budowlanej odmawia dopuszczenia jej do postępowania ze względu na przesłankę podmiotową, natomiast $\mathrm{w}$ przypadku dokonania takiego zgłoszenia 
Postępowanie w sprawie wydania pozwolenia na budowę...

w postępowaniu niewymagającym udziału społeczeństwa, z uwagi na bezprzedmiotowość wniosku.

\section{Poinformowanie organizacji ekologicznej o dopuszczeniu jej ex lege do udziału w postepowaniu na prawach strony}

Pomimo iż w przypadku braku przesłanek negatywnych do dopuszczenia organizacji ekologicznej do udziału w postępowaniu, przepis art. $44 \mathrm{ww}$. regulacji prawnej nie wymaga żadnej czynności organu prowadzącego postępowanie główne, to słusznym jest poinformowanie zgłaszającego o dopuszczeniu go ex lege do udziału w postępowaniu na prawach strony. Powinno to nastąpić z uwagi na wyrażoną w art. 9 k.p.a. zasadę udzielania informacji. Postanowienie o odmowie przyjęcia zgłoszenia udziału w postępowaniu wymagającym udziału społeczeństwa organ może wydać bowiem w terminach określonych w przepisach art. 35 k.p.a. W tym czasie powstaje więc niepewność zgłaszającego, czy został on dopuszczony ex lege na prawach strony do postępowania, czy też organ odmówi mu postanowieniem takiego udziału. Są to niewątpliwie okoliczności, które będą miały wpływ na ustalenie jego praw. Jeżeli więc organ wystosuje do zgłaszającego pismo w tej sprawie, nie narazi się na zarzut naruszenia zasady informowania. Ponadto uczyni on zadość określonej w przepisie art. 8 k.p.a. zasadzie pogłębiania zaufania, zgodnie z którą organy administracji publicznej prowadzą postępowanie w sposób budzący zaufanie jego uczestników do władzy publicznej.

\section{Forma prawna zgłoszenia przez organizację ekologiczną udziału w postępowaniu}

Ustawa o udostępnianiu informacji o środowisku nie określa formy prawnej zgłoszenia przez organizację ekologiczną udziału w postępowaniu. W związku z czym zastosowanie znajduje tu przepis art. $63 \S 1$ Kodeksu postępowania administracyjnego, zgodnie z którym podmiot ten może zgłosić swoje żądanie pisemnie, telegraficznie, za pomocą telefaksu lub ustnie do protokołu, a także za pomocą innych środków komunikacji elektronicznej przez elektroniczną skrzynkę podawczą organu administracji publicznej. Wniosek taki musi czynić zadość wymaganiom formalnym określonym w przepisach art. $63 \S 2$-3a k.p.a. W przeciwnym razie organ prowadzący postępowanie główne w oparciu o przepis art. $64 \S 2$ k.p.a. wezwie organizację ekologiczną do usunięcia braków formalnych wniosku w terminie siedmiu dni z pouczeniem, iż nieusunięcie ich spowoduje pozostawienie podania bez rozpoznania. Organ może, stosownie do przepisu art. $64 \S 1$ k.p.a., pozostawić bez rozpoznania zgłoszenie organizacji ekologicznej również w przypadku, gdy nie poda ona w treści zgłoszenia swojego adresu, a nie będzie go można ustalić na podstawie posiadanych przez organ danych. Takie sytuacje w przypadku organizacji ekologicznych wydają się mało prawdopodobne, aczkolwiek możliwe. 
4. Chwila, z którą organizacja ekologiczna uzyskuje status podmiotu działającego na prawach strony $w$ postępowaniu

$\mathrm{Z}$ uwagi na powyższe określenie momentu, w którym organizacja ekologiczna uzyskuje status podmiotu działającego na prawach strony w postępowaniu wymagającym udziału społeczeństwa, może czasami budzić wątpliwość. Treść art. 44 ust. 1 ustawy o udostępnianiu informacji o środowisku wskazuje, iż następuje to ex lege w chwili dokonania zgłoszenia takiego uczestnictwa organowi prowadzącemu postępowanie główne, a więc $\mathrm{z}$ chwilą wpływu do organu wniosku organizacji ekologicznej w tym zakresie. Również w przypadku, gdy na skutek złożenia przez zgłaszającego zażalenia na postanowienie organu administracji architektoniczno-budowlanej pierwszej instancji o odmowie jej dopuszczenia do udziału w postępowaniu, właściwy organ drugiej instancji uchyli to rozstrzygnięcie, chwilą dokonania zgłoszenia będzie data wpływu wniosku do organu pierwszej instancji. Tak samo przedstawia się sytuacja, gdy organizacja ekologiczna zgłosiła swój udział do organu niewłaściwego, który na mocy przepisu art. 65 k.p.a. przekazał je do organu właściwego. Jeżeli organizacja ekologiczna w podaniu skierowanym do innego organu, obok żądań podlegających rozpatrzeniu przez niego, zgłosi swój udział w postępowaniu wymagającym udziału społeczeństwa, to stosownie do przepisu art. 66 $\S 1$ k.p.a. organ, do którego wpłynął taki wniosek, uczyni przedmiotem rozpoznania sprawy należące do jego właściwości. Równocześnie zawiadomi wnoszącego, że w sprawach innych powinien wnieść odrębne podanie do właściwego organu, informując go o treści przepisu $\S 2$ tego artykułu. Stosownie do tej regulacji odrębne podanie złożone przez wnioskodawcę zgodnie z powyższym zawiadomieniem, $\mathrm{w}$ terminie 14 dni od daty jego doręczenia, uważa się za złożone w dniu wniesienia pierwszego podania, czyli w dniu jego wpływu do organu niewłaściwego. Jeżeli w tym terminie wnioskodawca nie zwróci się do organu administracji architektoniczno-budowlanej prowadzącego postępowanie w przedmiocie wydania pozwolenia na budowę, wymagające udziału społeczeństwa, to zgłoszenie udziału w nim, dokonane przed organem niewłaściwym, nie wywiera skutku prawnego.

\section{Prawa i obowiązki organizacji ekologicznej uczestniczącej na prawach strony $w$ postępowaniu}

Organizacja ekologiczna w postępowaniu wymagającym udziału społeczeństwa działa na prawach strony. Należy zauważyć, iż pojęcie „uczestnik na prawach strony" nie zostało zdefiniowane w Kodeksie postępowania administracyjnego. ${ }^{30}$ Taki uczestnik występuje w postępowaniu fakultatywnie obok strony postępowania, a nie zamiast niej. Fakultatywność polega na dowolności wszczęcia bądź przystąpienia do toczącego się już postępowania. Katalog praw i obowiązków uczestnika na prawach strony $\mathrm{w}$ postępowaniu nie jest tożsamy $\mathrm{z}$ przysługującymi stronie 
uprawnieniami oraz ciążącymi na niej obowiązkami. ${ }^{31}$ Przede wszystkim podmiot biorący w postępowaniu administracyjnym udział na prawach strony nie musi wykazywać się w tym względzie interesem prawnym. Posiada on wówczas ,wszystkie uprawnienia procesowe strony, ale nie te, które wynikają z przepisów materialnoprawnych, w szczególności nie dysponuje prawami i obowiązkami materialnoprawnymi strony, jak i pewnymi procesowymi". ${ }^{32}$ Przykładowo podmioty na prawach strony, a więc i organizacje ekologiczne, nie mogą wystąpić z wnioskiem o zawieszenie postępowania, ani o jego umorzenie. Nie jest dopuszczalne wycofanie przez te podmioty wniosku wszczynającego postępowanie ani też zawarcie ugody administracyjnej. Jak wynika z powyższego, nie mogą one swobodnie rozporządzać przedmiotem postępowania.

Podstawowym uprawnieniem organizacji ekologicznej biorącej udział w postępowaniu wymagającym udziału społeczeństwa wynikającym z przepisu art. 29 ustawy o udostępnianiu informacji o środowisku jest składanie w jego toku uwag i wniosków. Stosownie do przepisu art. 44 ust. 2 ww. ustawy może ona także złożyć odwołanie od decyzji wydanej w postępowaniu wymagającym udziału społeczeństwa, jeżeli jest to uzasadnione jej celami statutowymi, nawet wówczas, gdy nie brała udziału w postępowaniu prowadzonym przez organ pierwszej instancji. Złożenie odwołania jest równoznaczne ze zgłoszeniem udziału na prawach strony w postępowaniu, dlatego też bierze ona udział w postępowaniu odwoławczym ex lege. Ocena, czy dany podmiot faktycznie miał legitymację do złożenia odwołania, a co za tym idzie do działania na prawach strony w postępowaniu, należy do organu odwoławczego, który w tym przedmiocie może wydać postanowienie odmawiające udziału w nim. Ponadto na podobnych warunkach, na mocy art. 44 ust. 3 ustawy o udostępnianiu informacji, od decyzji wydanej w postępowaniu wymagającym udziału społeczeństwa organizacji ekologicznej służy skarga do sądu administracyjnego.

\section{Podsumowanie}

Udział organizacji ekologicznych w postępowaniach wymagających udziału społeczeństwa w sprawach dotyczących wydawania pozwoleń na budowę inwestycji mogących oddziaływać na środowisko jest niewątpliwie potrzebny. Należałoby jednak zastanowić się nad stworzeniem instytucji prawnej zapobiegającej nadużywaniu przez organizacje ekologiczne swoich uprawień do celów prywatnych. W praktyce dochodzi bowiem do patologii polegającej na umyślnym „blokowaniu” inwestycji, przez uczestników postępowania w celu uzyskania przez nich korzyści, najczęściej o charakterze majątkowym. W takich przypadkach nawet zamierzenie inwestycyjne zaprojektowane z najwyższą starannością, zgodnie z obowiązującymi przepisami

32 W. Radecki, Instytucje prawa ochrony środowiska..., op. cit., s. 334. 
prawa, może przez wiele lat nie zostać ostatecznie zatwierdzone przez organy władzy publicznej. Stwarza to niekomfortową sytuację dla inwestora, który po długotrwałych staraniach często $\mathrm{w}$ ogóle rezygnuje $\mathrm{z}$ danego zamierzenia budowlanego bądź decyduje się na zrealizowanie go w innym miejscu. 


\section{THE ISSUE OF A BUILDING PERMIT WHICH IS REQUIRED FOR PUBLIC PARTICIPATION WITH PARTICULAR EMPHASIS ON THE APPLICATION FOR PARTICIPATION IN THE PROCEEDINGS OF ENVIRONMENTAL ORGANIZATIONS}

This subject of this article is the issuance of building permits for the development of projects in which environmental organizations take an interest and where the approval process is open to public scrutiny and participation. It describes the application process and public participation procedure and highlights the relationship between the environmental impact report and issuance of the permit. The paper goes on to define the environmental and social organizations that can be involved and their respective roles in the approval or rejection of a building permit.

Keywords: environmental organizations, procedure requiring public participation, building permit 